Int. J. Adv. Eng. Pure Sci. 2019, $179-187$

DOI: 10.7240/jeps.516022

RESEARCH ARTICLE / ARAŞTIRMA MAKALESI

\title{
Structural and Seasonal Differences of Syconia in Dioecious F. carica L.
}

\author{
Dioik F. carica L.’da Sikonyumların Yapısal ve Mevsimsel Farklılıkları \\ Özlem AYTÜRK ${ }^{1}$ \\ ${ }^{1}$ Maltepe Üniversitesi, Gastronomi ve Mutfak Sanatları Bölümü, 34857, İstanbul, Türkiye
}

\begin{abstract}
This research is part of the first quantitative, detailed study on the syconia in dioecious Ficus carica. Syconia were collected to research the phenology and sexual speciality of fig trees. Asynchronous syconium production was observed at a population level. They occurred three times yearly: in spring (December to March), in summer (July to September) and in autumn season (september to November). Syconium structure chart out quite differently; a syconium cosists of a receptacle, scale-like bracts surrounding the ostiole and flowers. Male, gall or female flowers bear into syconium, which are located on the inside surface of the syconium. We have been investigated the syconium in spring, summer and autumn periods. The morphological differences of gall and female flowers in spring and summer are obvious whereas the male flowers do not show any differences. F. carica found out variation in the fruits (syconium) to his survival. In this paper, time of formation and development of syconium have been investigated and compared.
\end{abstract}

Keywords: Dioecious tree, Ficus carica, phenology, syconia, sexual differentation.

$\ddot{O} \mathbf{z}$

Bu araştırma, diok Ficus carica'nın sikonyumları üzerine yapılan ilk detaylı ve kantitatif çalışmanın bir parçasıdır. İncir ağaçlarının fenolojisini ve cinsel özelliklerini araştırmak için sikonyumlar topland1. Asenkron sikonyum oluşumu popülasyon düzeyinde gözlendi. Sikonyumların yılda üç kez meydana geldikleri görüldü: ilkbaharda (aralık-mart), yaz aylarında (temmuz-eylül) ve sonbaharda (eylül-kasım). Sikonyumun yapısı oldukça farklı bir oluşum sergiler; ostiolü çevreleyen pul benzeri brakteler, reseptakulm ve çiçeklerden oluşur. Erkek çiçekler, sikonyumun iç yüzeyinde bulunan doku üzerinde oluşurlar. Sikonyumlar ilkbahar, yaz ve sonbahar dönemlerinde incelendiğinde ilkbahar ve yaz aylarında gal ve dişi çiçeklerin morfolojik farklılıklar gösterdiği oysa ki erkek çiçeklerde hiçbir farklılığın olmadığı açıktır. Sonuç olarak F. carica'da sikonyumlar hayatta kalmak için değişiklikler oluşturmuşlardır. Bu çalışmada sikonyumların oluşumu ve gelişim zamanları araştırılmış ve birbiriyle karşılaştırılmıştır.

Anahtar kelimeler: Diok ağaç, Ficus carica, fenoloji, sikonyumlar, eşeysel farkl1laşma.

\section{INTRODUCTION}

The 900-odd species of Ficus [1, 2, 3] establish the most clear of the widespread genera of tropical plants [4]. Ficus carica L. (Moraceae) is very important species because over 700 type of Ficus spp. worldwide are mutualistically associated with extremely host-specific ficus wasps (Blastophaga psenes, Agaonidae) for pollination [5, 6, 7]. In the Ficus species, particularly in F. carica, complicated reproductive biology; flower morphology, pollination and the details of the wasp behavior have been studied in general conditions $[8,9,10,11]$.

The fig tree produces enclosed inflorescences (syconia), commonly called figs. F. carica are discernibled as a genus by the syconium, a original covered inflorescence which also functions like a pseudocarp [12]. It has a cycle involving three flowers morps [long-styled female, short-styled female (gall), male] located in the syconium. Approximately one-half of all fig species are gynodioecious, while the rest are monoecious, with both male and female flowers in an individualistic syconium. Latest studies, specially in phylogenetics, has advanced our understanding of the models of evolution and 
coevolution of Ficus sp and wasps. Combined studies of this model system presently providing excellent opportunities to investigate general issues $[13,14,15]$.

Syconia make real many important tasks. For example, it conserve flowers and wasp (Blastophaga psenes). The other task, syconia produce semiochemicals that attract only the specific fig wasp pollinator to the flowers via an ostiole [16], an entrance pore that is filled with a whorl of bracts that screen out most other insects [17, 18, 19]. Actually, it serves to genetic diversify of F. carica. Syconia are considered to be key plant resources in tropical rainforests owing to their heavy and sustained production, supply food for a range of frugivores (particularly birds) along periods of fruit shortage $[4,20]$.

In this paper, we tried to find out the answers of the following questions: What are the models of syconium form phenology of Fig ? How are syconia modify to construct its phenology and development to suitable the life cycle of its pollinating wasp, as discovered in another "fig-wasp" mutualisms?

\section{MATERIAL AND METHODS}

We collected syconium (inflorescence of fig) in natural environment, from Göztepe Campus of Marmara University (Istanbul / Turkey), as of October 2011 until June 2014. In four generation, syconium traits observation altogether 500 syconia were sampled during this study. Syconia in the allphase were collected.

\subsection{Stereomicroscope Analysis}

Firstly, female and male syconium were morphologically analysed. We dissected the syconia and observed it under a digital stereomicroscope (Olympus 970931). In these syconia, the short-styled female flowers (gall), male flowers and female flowers were checked and photographed using a digital camera (KAMERAM software). The lengths of syconium parts; flower, receptacle and brakte were measured by stereomicroscope and the examples were prepared for light microscopy and SEM analysis.

\subsection{Light Microscopy Analysis}

For light microscopy analysis, the material was fixed in FAA (37\% formaldehyde:acetic acid: ethanol:dH2O, 10:5:50:35) solution and after that placed in a vacuum desiccator to simplify the penetration of the fixative into the tissues. After dehydration in a graded series of ethanol, the material was embedded in paraffin. The sample blocks were sectioned at
3-8 $\mu \mathrm{m}$ by Leica RM2235 rotation microtome and examples were spotted with Delafield's hematoxylin stain. Development of syconium parts were revealed step by step with light analysis in the both male and female trees.

\subsection{Sem Analysis}

For SEM analysis, the plant material was fixed in $2.5 \%$ glutaraldehyde in $50 \mathrm{mM}$ cacodylate buffer, $\mathrm{pH} 7.0$ and then dehydrated with an increasing ethanol gradient: from $70 \%$ up to $100 \%$. After that, the sample for drying was kept in various percentages of ethanol-HMDS solution at room temperature. Then, it was covered with $11 \mathrm{~nm}$ of gold by using an automated sputter coater and then analyzed with a SEM (JEOL JMS-59 10LV). Development of syconium was showed with SEM analysis in the both male and female trees.

\section{RESULT}

In the figs, trees are two morphs; male and female. There were adequate degrees of both synchrony and asynchrony among the female and male trees to maintain pollinator production. The trees bear syconia throughout the year and they occurred three times yearly: in spring season (December to March), summer season (July to September) and in autumn season (september to December) (Tablo 1). The female and male fig trees initiate producing new syconia while unripe syconia of the former crop were still on the trees.

Tablo 1. The time of the syconia formation in male and female trees of Ficus carica L.

\begin{tabular}{|c|c|c|c|c|c|c|c|c|c|}
\hline \multirow[b]{2}{*}{$\begin{array}{l}\text { Sex of } \\
\text { tree }\end{array}$} & \multicolumn{3}{|l|}{ Spring } & \multicolumn{3}{|c|}{ Summer } & \multicolumn{3}{|c|}{ Autmun } \\
\hline & march & april & may & jun & july & august & $\begin{array}{l}\text { sep- } \\
\text { tem- } \\
\text { ber }\end{array}$ & $\begin{array}{l}\text { octo- } \\
\text { ber }\end{array}$ & $\begin{array}{l}\text { novem- } \\
\text { ber }\end{array}$ \\
\hline male & 4. week & & & & 4. week & & * & & \\
\hline female & & 1.week & & & 1. week & & $*$ & & \\
\hline
\end{tabular}

* The new syconium does not occur. But, the old syconia from the previous period starts to develop.

\subsection{Periods of syconium formation in male and female trees}

In both fig trees, bear three floral forms in the syconia; gall, male (on the male tree) and female (on the female tree). Fig wasp (Blastophaga psenes) also called fig insect is deposited inside the gall flower structure. 


\subsubsection{Spring season (December to March)}

In male trees, new male syconia (nm-sp) buds occur in the fourth week of March. Alongside, numerous and expanded old male syconia (om-sp) buds located keep in since that time that bear during the previous summer period. The gall flowers of these om-sp carry the wasp larvae in this stage. While in a few gall flowers have endosperm or embryo, male flowers have pollen (Tablo 2). The nm-sp buds expand from July to August and are protected on the tree until the fertilization time of female flowers (nf-su) while the om-sp buds fall from on the trees before the month of August (Figure 1).

In the female trees, female spring syconia (nf-sp) buds occur in the first week of April. Numbers of nf-sp are almost up to the nm-sp. The nf-sp continue to develop during the summer. Also, female trees as male have old female syconia (of-sp) buds that expands beginning in July at the previous summer period. Number of the of-sp are quite a few, unlike om-sp. The nf-sp and of-sp become empty and abscise as nm-sp of the previous summer male trees, before the month of August (Figure 1). While in a few female flowers have endosperm, embryo or seed, these syconia do not carry male flowers hence there are no pollen (Tablo 2).

Tablo 2. The products of the syconia in the male and female trees during the whole year.

\begin{tabular}{|c|c|c|c|c|c|c|}
\hline \multirow[t]{2}{*}{ months } & \multicolumn{2}{|l|}{$\begin{array}{l}\text { march } \\
\text { april }\end{array}$} & \multicolumn{2}{|l|}{$\begin{array}{l}\text { Jun } \\
\text { july }\end{array}$} & \multicolumn{2}{|c|}{$\begin{array}{l}\text { september } \\
\text { october }\end{array}$} \\
\hline & \multicolumn{6}{|c|}{ Sex of tree } \\
\hline bear in syconium & $\sigma^{2}$ & 우 & $\sigma^{\prime \prime}$ & O & $0^{x}$ & 우 \\
\hline wasp & larva & & ergin & & $*$ & \\
\hline Pollen & ++ & & +++ & & + & \\
\hline Embryo sac & + & + & + & + & + & - \\
\hline Endosperma & + & + & + & + & + & - \\
\hline Seed & - & + & - & ++ & $+($ rare $)$ & + \\
\hline
\end{tabular}

* The larvae become adults around in the most of syconium, the same time other some syconia are to produce larvae same on the male tree.

\subsubsection{Summer season (July to September)}

In the male trees, new summer syconia (nm-su) again occur in fourth week of July. Numbers of the nm-su buds are less than male trees of the spring time. The nm-su buds continue form until the end of summer of the this year but they are not mature, only located keep on these trees. Also, remaining from the spring the nm-sp and om-sp are still located keep on this tree in this period. When the om-sp of spring reach to walnut size the female wasps mature into the gall flowers. When the nm-su reach size of hazelnuts, the female wasps leave their eggs into the gall flowers. The female wasps lead to collect pollen of om-sp and female trees causing the formation of edible fruits. While in a few gall flowers have endosperm or embryo, male flowers have pollen like the spring season (Tablo 2). The formation of pollen grains in the nm-su of summer and spring periods and their numbers are very few unlike the om-sp. They are not used for fertilization (Figure 1).

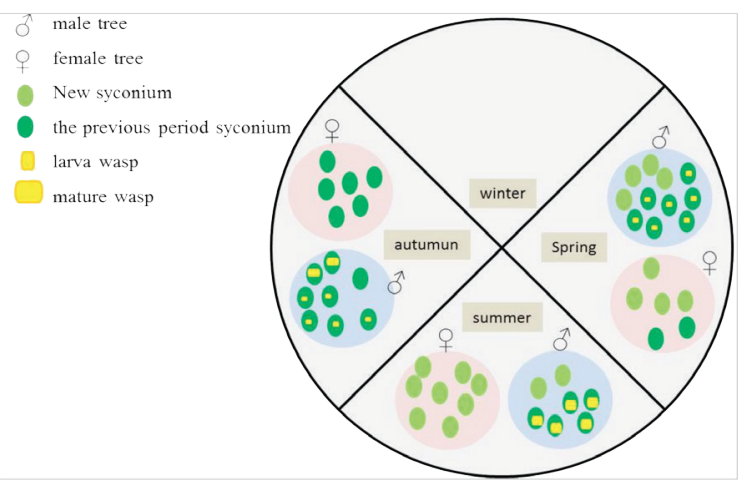

Figure 1. The expression of product variability in a year in the male and female syconia.

In the female trees, new syconium (nf-su) buds again occur so long before from the male trees, in the first week of July. Unlike male trees, the female trees bears more syconia than the spring. A few female flowers have endosperm, embryo or seed like the spring season (Tablo 2). The nf-su continue to grow during the summer, and they expand and reach a state where edible fruit will form at the end of summer. The nf-su are fertilized by the pollen grains that created on om-sp of male trees in the spring.

\subsubsection{Autumun season (September to December)}

In the male trees, the new syconia buds do not occur. But there are two types syconia on these trees: 1 . few mature syconia that carrying adult wasp, 2. large number of immature syconia carrying wasp larvae. In this period, immature $\mathrm{nm}$-su start to develop. While immature nm-su stay on the male tree during the winter, mature nm-su fall before Spring (Tablo 2).

In the female trees, In this period, new syconia buds do not occur on female trees as the male trees. In October, all syconia fallen so, no Spring syconia in female trees unlike men trees (Tablo 2).

\subsection{Formation and Development of the Syconium}

The morphology of the syconia were identified by using streo - and light microscopy. Development differences of male and female syconia were investigated through the 
usage of scanning electron microscopy (SEM) and light microscopy analysis.

Syconia buds start to develop around the eyes on the in male and female trees and on the leaf seats (Figure 2a,b). In the apical meristem stage in the male and female syconium (presyconium) are very small $(\sim 4.1 \pm 0.7 \mathrm{~mm})$ and dark green (Figure 2b).

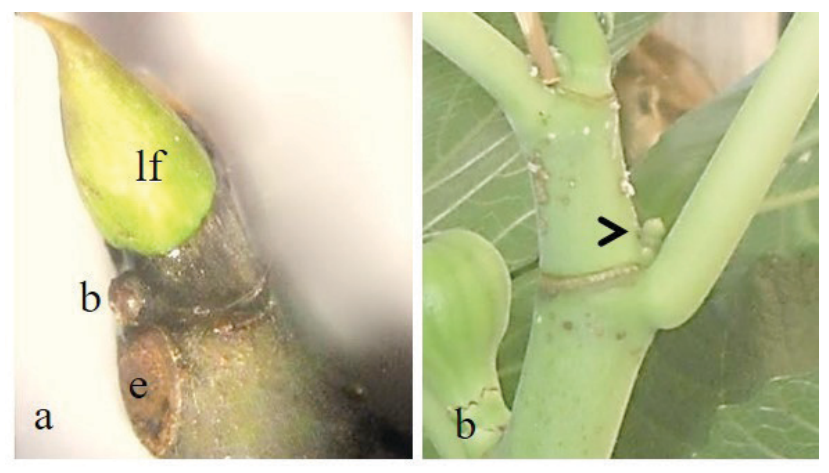

Figure 2a. The growth location of consisting syconia in the trees*. b. The flowers that in the apical meristem stage into young syconium (arrow)*. e. eye, b. flower or leaf bud, lf. leaf bud. * male syconia were only shown in here because of male and female syconia exhibited similar morphology all these stages.

In both fig trees, a syconium includes the receptacle tissue, stamp (brakte) and flowers (female or male and gall). In the male and female syconium, receptacle bear the big fleshy structure piece of syconium. In the female and male syconia, bracts are located on at the base of syconium and they set up the opening named ostiol in the middle of bracts.

Young syconium stage (before fertilization)

In the early stages (apical meristem exists), the receptacle is flat when it bears flowers, the thickness is $0.8 \pm 0.3 \mathrm{~mm}$ (Figure 3a-c; 4a). The outward facing it surrounds a hard cover (Figure 3a-c) when the syconia were tightly closed with ostiolar bracts (Figure 3a-c; 4b,c; 5a; 6a-c). The syconium cavity is nearly full of bracts. Dimension of ostiol clearance is the same in the male and female syconia. Flowers are arrayed throughout reptaculum wall in the male and female syconium (Figure 4d,e) and are quite small according to bracts (Figure 3a-c; 5b; 6d). In the male and female syconia have different flowers in sex and in arrangement. Newly formed syconia swelling quickly, female flowers grow in female syconia also male and gall flowers develop in male syconia (Figure 3a-c). Male flowers are formed near the ostiol and gall flowers are formed on the whole surface of the receptacle (Figure 3d; 5c). Also, there are only female flowers that covering the entire surface in the female syconium (Figure $3 \mathrm{e}, \mathrm{f} ; 6 \mathrm{e})$. In the outer epidermis of the covering, with the development of syconia pointed-single-celled and multicellular hairs are seen in the male and female syconia (Figure $3 \mathrm{e}, \mathrm{f} ; 6 \mathrm{f})$.

\subsubsection{Mature syconium stage}

In this stage, syconium color changes from dark green to light green. The syconium cavity is not narrow in this phase (Figure 3g). In the male and female, the receptacle is pit and deepen with the development of syconia (Figure $3 g, h$ ). While flowers develops in the receptaculum, the reseptaculum thickness reaches about three times, $2.4 \pm 0.5 \mathrm{~mm}$. Bracts sliding upper pole of the syconium and surrounded the ostiol up to the mature flowers stage (Figure 3h). Also, in the female syconium close to fertilization ostiol clearance even more grow. The numerous female (Figure 3i) or gall flowers (Figure $3 \mathrm{j}$ ) cover most of the inner surface of the syconium. The gall flowers in the syconia become mature while male flowers (Figure 3k) develop quickly into the visible form. Male flowers mature, producing pollen in male syconia. Simultaneously, Female flowers are receptive to pollen in this stage. The female syconia become soft, fleshy (Figure 31) and attractive to wasps.

\subsubsection{Old syconium stage}

The syconium become green, with cream spots on the superficial. At the later stage of the stage, syconia become green-yellow and eventually abscise from trees. The mean of syconium diameter of the female flower stage was $10.4 \pm 0.3$ $\mathrm{cm}$, and arrived $8.8 \pm 0.2 \mathrm{~cm}$ of the gall flower phase. Ostiole is relatively loose. 

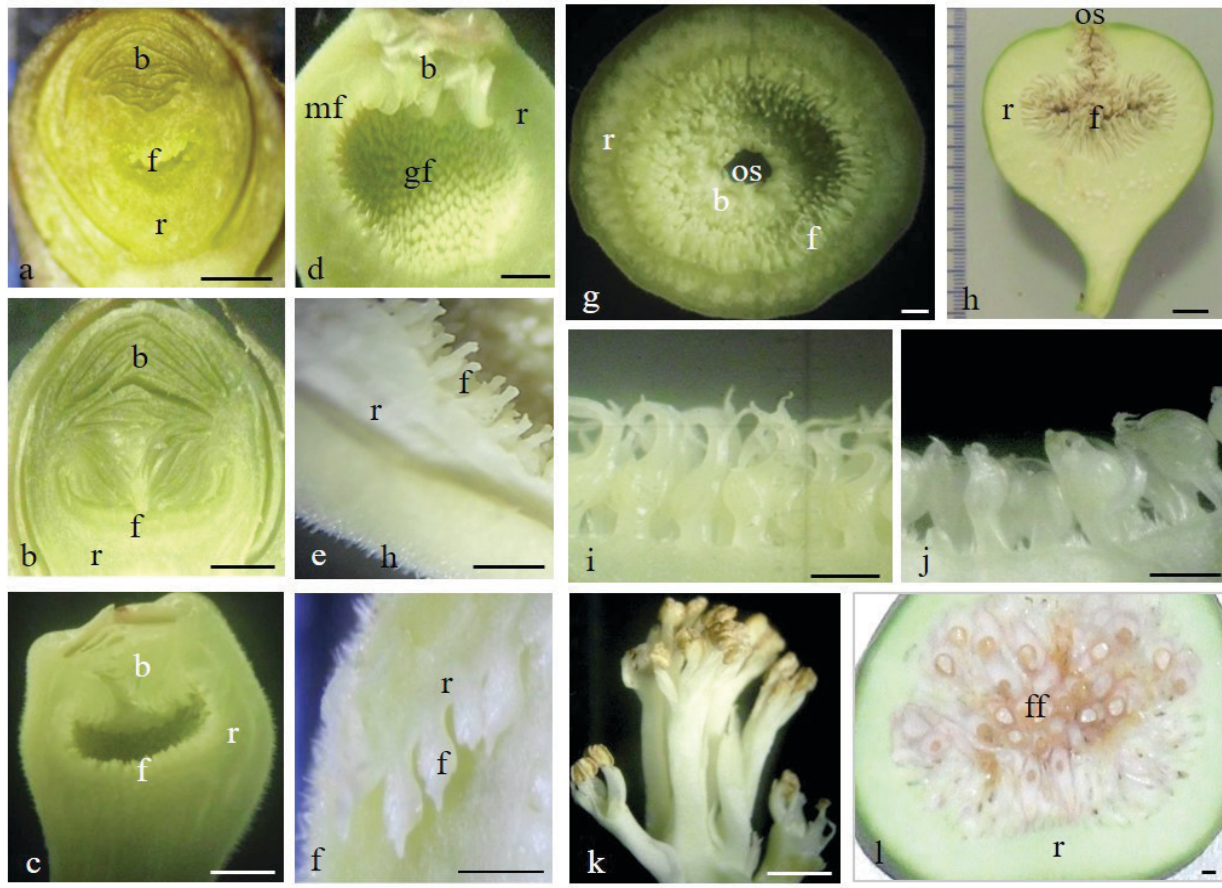

Figure 3. Stereomicrographs show orientation of receptaculum, bracts and flowers of a syconium* at the different stages of development. Longitudinal (a-d, h-k) and transversal (e-g,l) sections. a-d; Apical meristem (a), floral meristem (b), initiation of stamens or carpel (c) in the flowers cover most of the inner surface of the female syconium. d. mature flower stages; male flowers are formed near the ostiol and gall flowers are formed on the whole surface of the receptacle. e, f. Flowers are arrayed throughout reptaculum wall, g.h. Bracts sliding upper pole of the syconium and surrounded the ostiol up to the mature flowers stage. i-k. Mature flowers; female (i), gall (j), male (k). 1. The numerous female flowers after fertilization. b. bract, f. flower, ff. female flower, gf. gall flower, mf. male flower, os. ostiole, r. receptaculum. Scale bar, 1 mm. * male syconia were only shown in here (except Figure 3d) because of male and female syconia exhibited similar morphology all these stages.

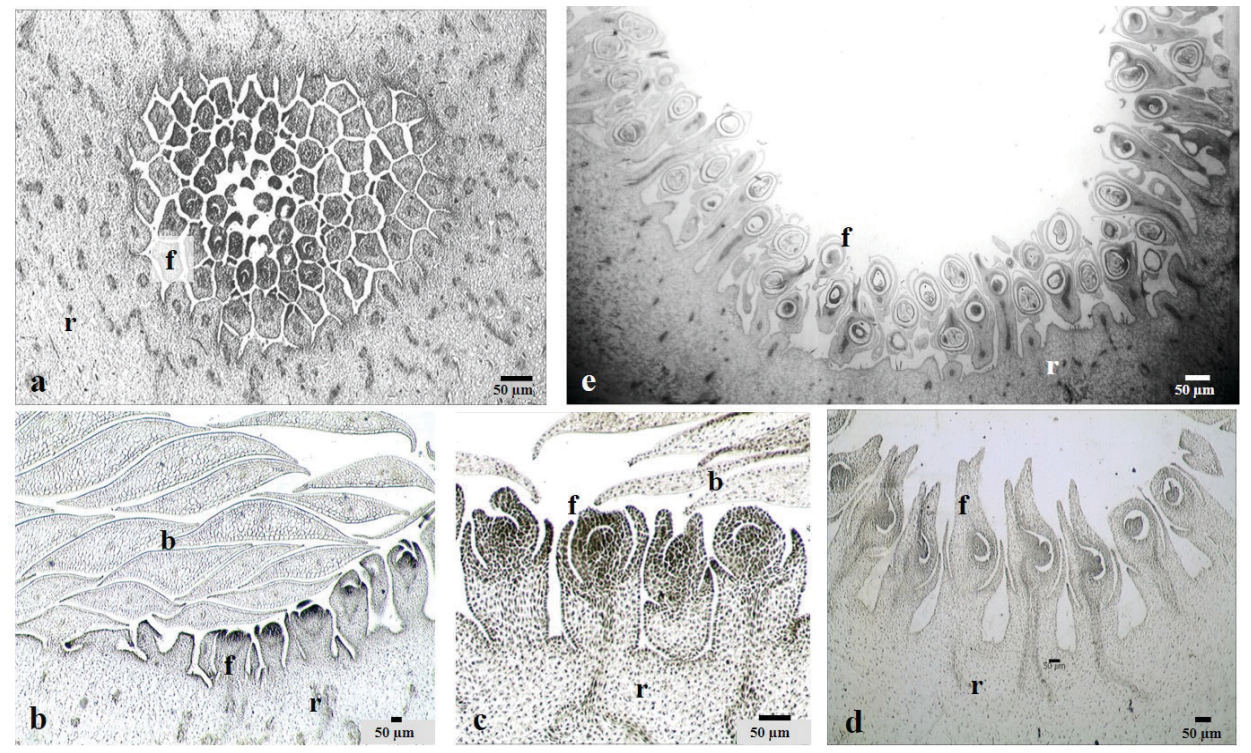

Figure 4. The light microscopy pictures show orientation of receptaculum, bracts and flowers of a syconium* at the different stages of development. a. floral meristem stage, b. initiation of carpel in the flowers; bracts tightly surrounded the ostiol up to, c. the pistil initiation of flower stage and bracts, d, e. Flowers are arrayed throughout reptaculum wall. b. bract, f. flower, r. receptaculum. * male syconia were only shown in here (except Figure 4b) because of male and female syconia exhibited similar morphology all these stages. 

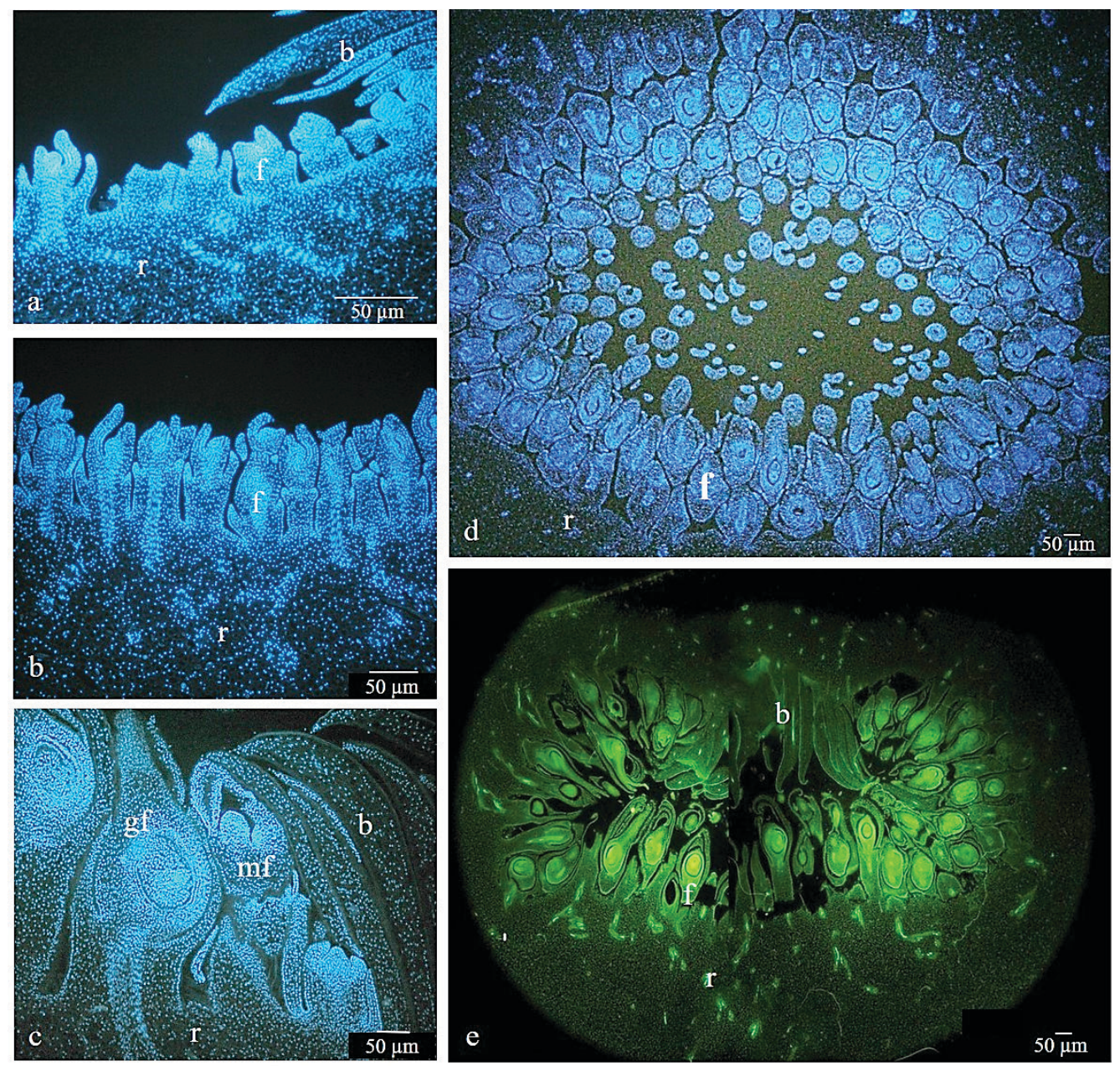

Figure 5. Fluorescence micrographs show orientation of receptaculum, bracts and flowers of a syconium* at the different stages of development. a. floral meristem stage (flowers under the bracts), b. initiation of carpel in the flowers on the whole surface of the receptacle c. Bracts sliding upper pole of the syconium and surrounded the ostiol up to the mature flowers stage, d. male flowers are formed near the ostiol and gall flowers are formed on the whole surface of the receptacle, e, Flowers are arrayed throughout reptaculum wall, f. Bracts tightly surrounded the ostiol up to the after fertilization. b. bract, f. flower, gf. gall flower, mf. male flower, os. ostiole, r. receptaculum.

* male syconia were only shown in here (except Figure $5 \mathrm{c}$ ) because of male and female syconia exhibited similar morphology all these stages. 

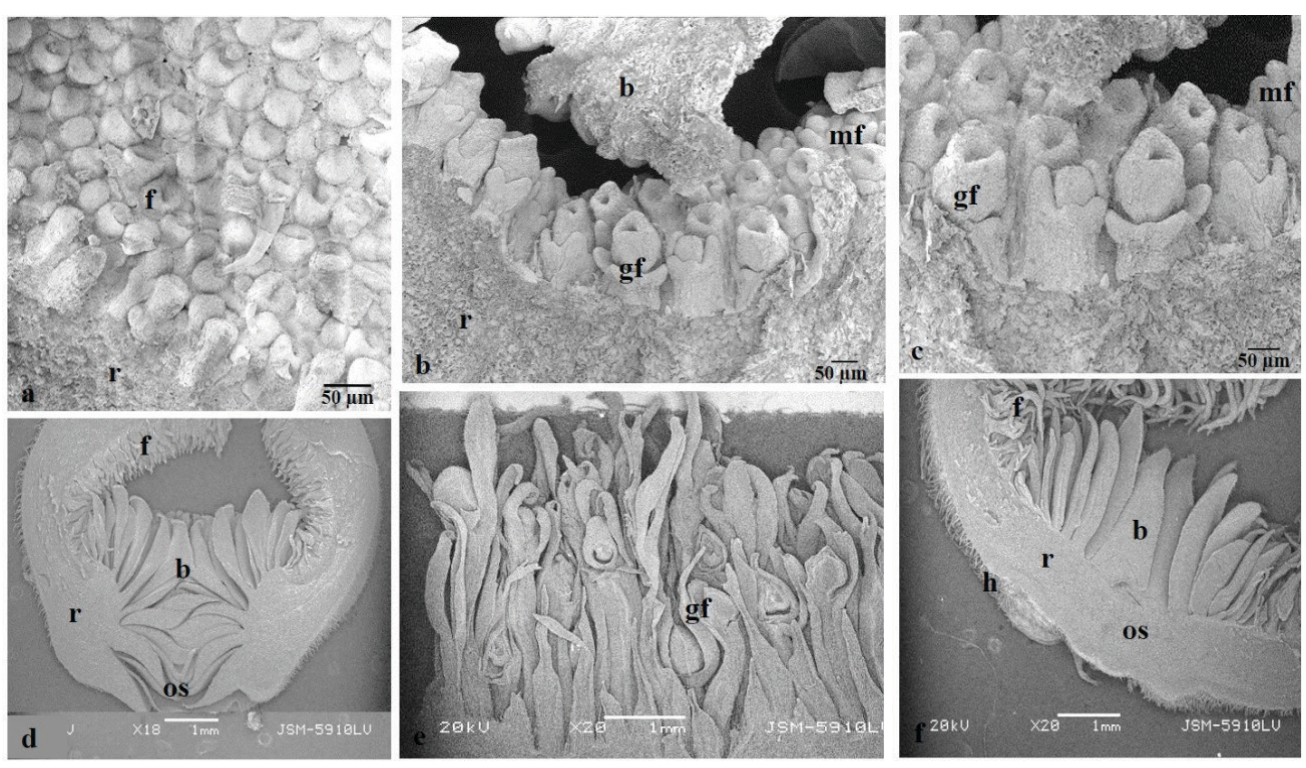

Figure 6. Scanning Electron (SEM) micrographs show orientation of receptaculum, bracts and flowers of a syconium* at the different stages of development. a. floral meristem stage, b. initiation of carpel in the flowers; male flowers are formed near the ostiol and gall flowers are formed on the whole surface of the receptacle c. With higher magnification of the marked portion of b. d. Bracts sliding upper pole of the syconium and surrounded the ostiol up to the mature flowers stage, e. Flowers are arrayed throughout reptaculum wall, f. Bracts tightly surrounded the ostiol up to the after fertilization. b. bract, f. flower, gf. gall flower, mf. male flower, os. ostiole, r. receptaculum. * male syconia were only shown in here (except Figure $6 \mathrm{~b}, 6 \mathrm{c}$ ) because of male and female syconia exhibited similar morphology all these stages.

\section{DISCUSSION}

The diversity of dioecious figs and the plenty of ways in which sex differentiation has formed, makes suggesting ways in which dioecy may have evolve well easy [21, 22]. In Fig. (Moraceae) there are two breeding structures: monoecy is the ancestral status but almost half the 750 odd species are functionally dioecious plant [23]. Ficus carica story brings to mind many questions in Plant Embryology. This research is an effort to know the questions. In this work, trees were observed throughout the year and that result obtained, yes, F. carica is good example " the plenty of ways".

According to Galil and Eisikovitch [24], for the understanding of the life history of each syconium should be observed separately. In the previous study, Janzen [25] mentioned from the difference between male and female tree syconia. Furthermore, we observed like Janzen [25] two neighboring syconium may differ from each other considerably; in both male and female syconium support the hypothesis that selection for sexual specialization has strongly influenced the reproductive biology of this species.

We observed F. carica bears syconium throughout the year. Syconia were produced asynchronously on the trees of male and female, and there were adequate grades of both synchrony and asynchrony among female and male plants to protect pollinator generation along the year. In addition, we observed that female and male trees started producing new syconia while immature syconia of the previous crop were still on the trees. Galil - Eisikovitch [24] observed a similar situation; as usual in the genus Ficus the syconium is precisely protogynous and there is an interval of several weeks between the maturation of the female and that of the male flowers.

In the light of the results taken from our previous study [7] we can say that, the summer period is more important than the other two periods. In F.carica, male trees released most wasps and pollen from mature male syconia in the summer season, during peak production of receptive female syconia. Because, the male flowers bear pollen in three periods but they have made too much the number of pollen during the summer and the pollen of this period provides insemination.

According to our, investigation number of the male syconia are quite a few, unlike female syconia in F. carica in the summer. Also, female trees only product edible syconium 
in this period. The our findings confirm to that knowledge, according to Patel and McKey [26], duration of developing phase was longer in female syconia of this species than in male syconia, very likely because they need a longer period of investment in a fleshy fruit. According to our observations, a good example of synchronization is the time of fertilization in the female flowers and the collecting time the pollen by the wasp in the male flowers that are parallel to each other.

In this study the duration of each stage in F. carica was defined by dissecting the syconium and identifying the characteristicals of the female and male syconium. In F. carica, the male and female trees produced more syconia in the summer and autumn season than in the spring. In the spring, the male and female trees occur a few new syconia and after a while they fall. In this period, the male and female syconia do not form edible fruit or pollen does not occur. Why does this syconia occur?, according to us, may be that is the answer of this question; the new syconia do to task as a new home for the larvae of the adult wasp of the old syconia.

There is a difference in spring and summer male figs and the time process for becoming available for receiving eggs and being pollinated. In the spring, male figs usually produce more wasps than summer male figs, do because of the better and more available resources of the spring figs compared to the summer. This suggest that the male fig wasp population is much more active and larger in the spring period. As the result of, the spring and summer male figs have a cycle related to each other as to maximize resources and output of figs and wasps.

These our results, it is important because of have similarities with results of Kjellberg et al. [27]. Cox [28] has obtained a result, 'such dioecious, sex differentiation may affect numerous characters, including structure of flowers and syconium, phenology, seed and fruit traits related to dispersal, or even physiological differences related to niche partitioning '. This study is one of the few on syconium in dioecious Ficus carica L. Previous studies examined reproductive success of dioecious. This research expands the observations previously. In this paper, time of formation and development of syconium have been investigated and compared. This research is part of the first quantitative, detailed, study on the syconia in dioecious F. carica. More over our data provide the possibility for further studies of the syconium of Ficus carica in female and male trees. For example, trees of F. carica are dependent on the wasps arriving from neighboring individuals is important result for experiments.

\section{CONCLUSIONS}

This paper show that, such a Ficus carica syconium structure brings to mind many questions in dioecious. Our study is an tryed to locate guide questions. For example, that is an important question: Fig are very diverse, and both monoecious and dioecious groups include a wide array of species. Until more species have been studied, and we have a obvious picture of the phylogenetic correlations between them, it is difficult to reliably establish correlated characters. Or, for example, syconium structure of $\mathrm{F}$. carica is a marvelous fruit; it has reinvented the multiple-ovuled ovary and many-seeded fruit however in a dioecious fig tree, F. carica, the fig wasp population can be maintained successfully within an male tree. Our findings support similar result but, all of our findings is limited a few another study. Moreover, this study may provide constructive suggestions for the conservation of biodiversity, because figwasp obligate mutual relationship.

\section{REFERENCES}

[1] Monselise, S.P., Figue, Fr., Feige, Ger., Fico, It., Higo, Sp., \& Julian, C.C. (2018). Handbook of Fruit Set and Development. Chapter Fig, Pages 14.

[2] Datwyler, S.L., \& Weiblen, G.D. (2004). On the origin of the fig: phylogenetic relationships of Moraceae from $\mathrm{ndhF}$ sequences. Am J Bot, 91, 767-777.

[3] Corner, E.J.H. (1962). The classification of Moraceae. Gard. Bull. Straits Settle - ment, 19, 187-252.

[4] Janzen, D.H. (1979a). How to be a Fig. Annual Review of Ecology and Systematics, 10, 13-51.

[5] Ji, L., Zhe, W., Li, C., Tinglin, Z., Qinwei, G., Jian X., Li, J., Qunfeng, L., Sanwen, H., \& Zhengguo, L. (2014). Transcriptome comparison of global distinctive features between pollination and parthenocarpic fruit set reveals transcriptional phytohormone cross-talk in cucumber (Cucumis sativus L.). Plant Cell Physiol, 55(7), 1325.

[6] FAO: Food and Agriculture Organization of the United Nations (2006). FAOSTAT agricultural data.

[7] Berg, C.C. (2003). Flora Malesiana precursor for the treatment of Moraceaea 1: The main subdivision of Ficus: the subgenera. Blumea, 48, 167-178.

[8] Aytürk, Ö. (2016). Comparison of Female, Gall and Male Flower Development with Microscopic and Molecular Tecniques in Dioecious Ficus carica L. PhD, Marmara University, Istanbul, Turkey.

[9] Flaishman, M.A., Rodov, V., \& Stover, E. (2008). The fig: botany, horticulture, and breeding. Horticultural Rev-Westport Then N Y., 34, 113.

[10] Stover, E., Aradhya, M., Ferguson, L., \& Crisosto, C.H. (2007). The fig: overview of an ancient fruit. Hortscience, 42, 1083-1087. 
[11] Ramirez, W. (1977). A new classification of ficus. Annals of the missouri botanical garden, 64, 296-310.

[12] Rosianski, Y., Freiman, Z.E., Cochavi, S.M., Yablovitz, Z., Kerem, Z. \& Flaishman, M.A. (2016). Advanced analysis of developmental and ripening characteristics of pollinated common-type fig (Ficus carica L.). Sci Hortic, 198, 98-106.

[13] Freiman, Z.E., Rosianskey, Y., Dasmohapatra, R., Kamara, I., \& Flaishman, M.A. (2015). The ambiguous ripening nature of the fig (Ficus carica L.) fruit : a gene expression study of potential ripening regulators and ethylene-related genes. $\mathrm{J}$ Exp Bot, 66, 3309-3324.

[14] Yu, D.W. (2001). Parasites of mutualisms. Biological Journal of the Linnean Society, 72, 529-546.

[15] Herre, E.A. (1999). In Laws Govering Species Interactions? Encouragement and Caution from Figs and their Associates. (Keller L ed) pp,209-237, Princeton University Press.

[16] Ware, A.B., \& Compton, S.G. (1994). Responses of fig wasps to host plant volatile cues. Journal of Chemical. Ecology, 20, 785-802.

[17] Bronstein, J.L. (1988a). Mutualism, antagonism, and the fig-pollinator interaction. Ecology, 69, 1298-1302.

[18] McKey, D. (1989). Population biology of figs: Applieations for conservation. Experientia 45, Birkh/iuser Verlag, $\mathrm{CH}-$ 4010 Basel/Switzerland.

[19] Bronstein, J.L. (1988b). Predators of fig wasps. Biotropica, 20, 215-219.
[20] Verkerke, W. (1989). Structure and function of the fig. Experientia (Basel), 45, 612-622.

[21] Sutton, T.L., DeGabriel, J.L., Riegler, M., \& Cook, J.M. (2017). Local coexistence and genetic isolation of three pollinator species on thesame fig tree species. Heredity, 118, 486490.

[22] Shuker, D.M., \& Simmons, L.W. (2014). The Evolution of Insect Mating Systems. Oxford University Press, Oxford, U.K.

[23] Wang, B., Geng, X.Z., Ma, L.B., Cook, J.M., \& Wang, R.W. (2014). A trophic cascade induced by predatory ants in a figfig wasp mutualism. Journal of Animal Ecology, 83, 11491157.

[24] Galil, J., \& Eisikovitch, D. (1974). Further studies on pollination ecology in Ficus sycomorus L. Pocket filling and emptying by ceratosolen arabicus magr. New phytologist, 73, 515528.

[25] Janzen, D.H. (1979b). How many babies do figs pay for babies?. Biotropica, 11, 48-50.

[26] Patel, A., \& McKey, D. (1998). Sexual specialization in two tropical dioecious figs. Oecologia, 115, 391-400.

[27] Kjellberg, L.F., Gouyon, P.H., Ibrahim, M., Raymond, M., \& Valdeyron, G. (1987). "The Stability of the Symbiosis between Dioecious Figs and Their Pollinators: A Study of Ficus carica L and Blastophaga psenes". Evolution, 41(4), 693704.

[28] Cox, P.A. (1981). Niche partitioning between sexes of dioecious plants. Am. Nat., 117, 295-307. 